\title{
The Football Fan Community as a Determinant Stakeholder in Value co-Creation
}

\author{
Patrizia Zagnoli, Elena Radicchi
}

Sport Management Laboratory, University of Florence, Italy

KEYWORDS

Fans are of central importance to sport service production. Their passion, excitement, and involvement plays a crucial role in event implementation and value creation. Due to the importance of fans as "co-producers" of the sport service, the hypothesis of this research is that a fan community is a salient stakeholder in the value co-creation process. This paper focuses on how a football fan community engages in manifold interaction with its team, the local context, and the network of actors as a whole. Within the theoretical framework of the stakeholders and the network approach, a multi-case analysis and thorough examination of the ACF Fiorentina's season ticket holders database enlightens a system of relationships where fans are able to influence the internal dynamics of the social network that has developed around the football club. In light of the empirical evidence presented by the case studies and the database on supporters, we propose a first typology of fans' roles and strategic behaviours. Findings, though not exhaustive, illustrate not only the roles assumed by fans during matches in terms of identification and participation, but also underline the variety of ways in which fans behave as stakeholders of their own team. In terms of value cocreation, this research highlights the fan community as a salient stakeholder and not just a mere spectator. Fans and supporters not only are crucial actors in implementing the sport service, but they even play an important role of influencing the choices and behaviours of the football club and other stakeholders.

football fan community, value co-creation, stakeholders, social network, local identity

\section{Introduction}

The new complexity of the sport sector has a strong impact on the implementation of sport products that nowadays are an expression of manifold subjects. The planning, production, distribution, and communication of sport content involves numerous actors who participate in the implementation of sport with diversified roles and importance: sport organizations, athletes, institutions and local administrations, sponsors, media, etc. Fans and supporters are of central importance, of course, to sport service production. The passion, excitement, and involvement expressed by the audience play a crucial role in event implementation and value creation. 
Due to the importance of fans as "co-producers" of the sport service, the hypothesis of this research is that a fan community is a salient stakeholder in the value co-creation process.

This research focuses on a football fan community that among different sports has one of the largest communities of supporters. Our choice was to study a specific professional football case, the ACF Fiorentina - the Florence, Italy football club - a "rich" example for identifying and analyzing the manifold influences and interactions that fans can engage in with their team, including the local context and the network of actors as a whole. This case study has profited from knowledge gained through several investigations, research and theses conducted within the Master's Degree in Sport Management program at the University of Florence. We started to monitor the football club and its relations with local stakeholders since 2003 - after the club's failure and its subsequent "rebirth" when the team went to an owner that for the first time ever was "non-Florentine" - up until the 2009/2010 football season.

To develop this case study a quali-quantitative methodology was used. The analysis of the fan community begins with an examination of the database of Fiorentina ticket season holders (Zagnoli et al. 2004), which highlights their socio-economic features. One-to-one interviews and focus groups conducted with fan club $^{1}$ representatives, the local chief of police, sport institutions, members of the football club (coach, managers, etc.) were also organised. Further meaningful information was retrieved through the monitoring of sport magazines and national newspapers, and the site searching of the ACF Fiorentina official web site, blogs and fan club web sites, in order to better explain data collected from interviews, focus groups and the database.

The complex context wherein fans move was studied by analyzing different subjects, with specific focus on the football club. The mapping of actors who are more or less linked to the existence of the Fiorentina was "guided" by the stakeholder theory. Nonetheless, this analytical tool does not seem to thoroughly explain all the relations developed within the sport sector. This approach (Freeman, Harrison, Wicks 2007, Harrison et al. 2009, Rowley 1997) is somewhat "corporatecentred". The analysis considers mainly the relationships activated by the "focal organization" with its stakeholders. Nevertheless, the aim of this literature is to understand how a firm can create value through transactions and relations established with each stakeholder.

Instead, this research analyses the relations within the sport network by focusing on a specific stakeholder that in economic terms constitutes the demand for which the product or service is destined, in respect to the focal organization. The local fan community, the Fiorentina's "user", interacts with manifold actors such as the players and coach, owners, local citizens, institutions, sponsors and suppliers, and media. By drawing on the theoretical tools of network analysis (Burt 1983, Freeman et al. 1992, Håkansson, Snehota 1995, Gummesson 2006, Mitchell et al. 1997, Rowley 1997, Salvini, 2007, Scott 2000, Wasserman, Faust 1994), it is possible to map the relations between the football club and its fans, as well as between fans and other stakeholders, by emphasizing the special network of the Fiorentina both in terms of internal dynamics as well as with regard to its connections with the external competitive football environment.

Even though the theoretical framework offered by the stakeholder theory and the network analysis give us an analytical lens for exploring the system of relationships developed around the football club, in particular that of Florence, these approaches have not offered specific analytical categories able to "read" the peculiarities of a sport community until now. By not exhaustively highlighting the role of the fan community in the value creation process, those theories leave space for a typological articulation related both to the fans' behaviour in regard to the match, and to strategic behaviour adopted by various subgroups of fans in the football sector.

\footnotetext{
${ }^{1}$ Associazione Centro Coordinamento Viola Club, Associazione Tifosi Fiorentina, Collettivo Autonomo Viola.
} 


\section{Mapping stakeholders of a professional football club}

The theoretical framework we decided to use to explore football fan communities is referred to as the Service-Dominant (S-D) Logic (Lusch, Vargo 2006a, 2006b) approach. One of the fundamental premises of this research recognizes a central role of networks and interactions in value creation.

Many of the actors in sport, with their different roles and capabilities, co-participate in the sport service and create a "constellation" of relations (Normann, Ramirez 1995) that produce value by implementing the sport product.

The stakeholder theory (Freeman 1984, Harrison et al. 2009) enables us to map the actors involved within the sport system. From the stakeholder's perspective, a firm - or more generally a "focal organization" (company, corporation, etc.) - is at the centre of a network of stakeholders (Harrison et al. 2009). According to the definition proposed by Freeman (Freeman 1984), this is "groups and individuals who can affect, or are affected by the strategic outcomes of a firm". Actors vital to the continued growth and survival of the organization can be grouped as primary stakeholders (Freeman 1984, Freeman, Harrison, Wicks 2007): customers, employees, management owners, suppliers, sponsors and local communities. Other groups that can affect or be affected by the focal organization are called secondary stakeholders: competitors, media, government, consumer advocate groups and special interest groups. Each of these can influence the relationship of the focal organization with the primary stakeholders (Freeman et al. 2007) ${ }^{2}$.

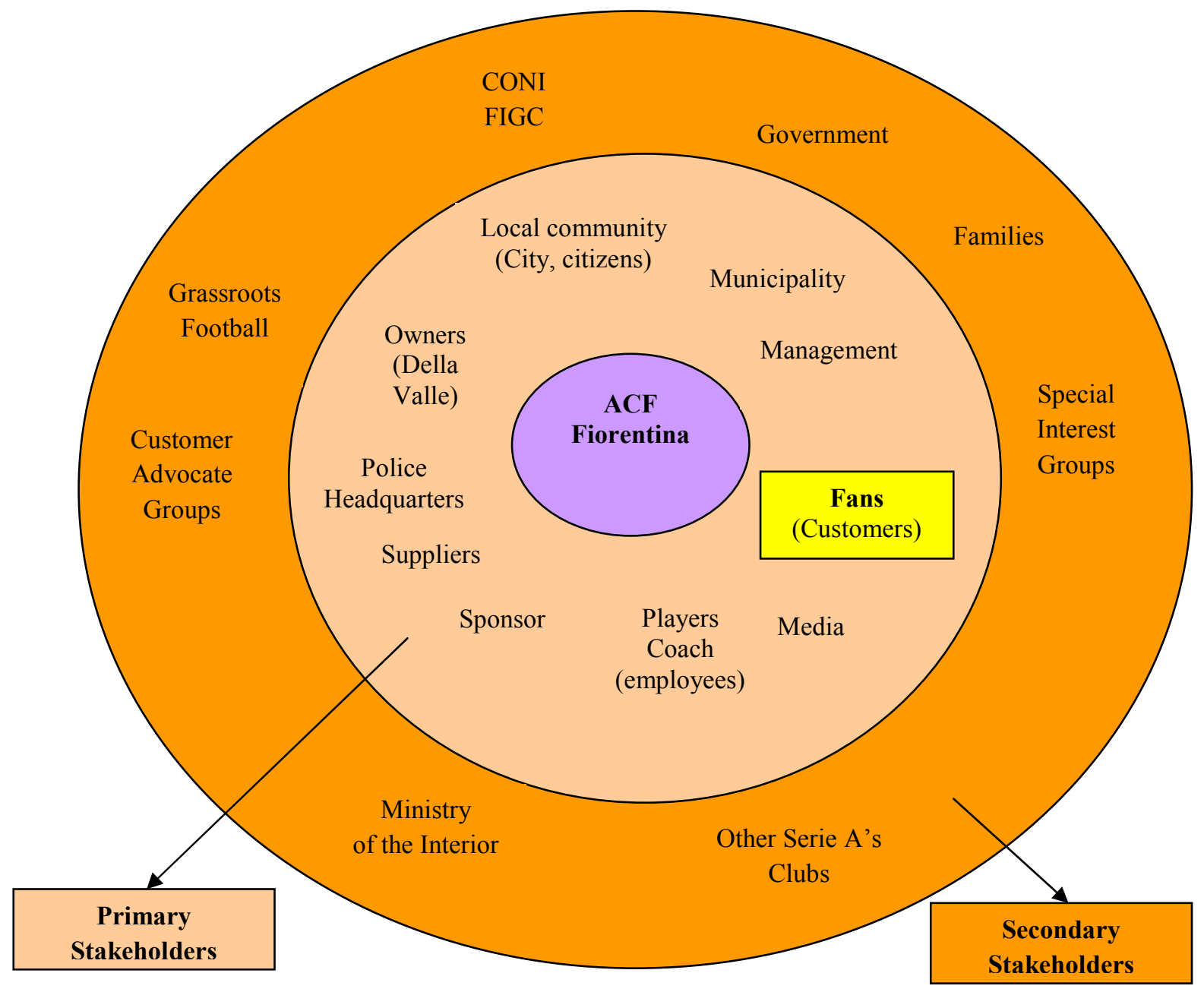

Figure 1. A stakeholder map for the Fiorentina football club Source: Adapted from (Freeman et al. 2007).

\footnotetext{
${ }^{2}$ For an in-depth examination of primary and secondary stakeholder' roles see Freeman, E. R. (1984). Strategic Management: A Stakeholder Approach. Pitman, Boston: MA.
} 
A particularly important empirical case, the ACF Fiorentina football club gives us some interpretative insight into the system of stakeholders with regards to a professional football club. In recent years the Fiorentina has undergone relevant changes in terms of ownership that for the first time ever is "not Florentine". This event has triggered a relationship process among the actors involved within the local system (fans, institutions, media, coach, top management, etc.) that has enriched the empirical framework as shown in figure 1.

The Fiorentina, the unique professional football club of Florence, is at the centre of a network of relationships with fans, spectators, players, coach, top management, media, sponsor, facilities managers, etc. who interact to implement the match end-product (figure1). The football club is the actor around which many subjects and interests rotate. The team is the entity that satisfies the emotional needs of fans. These are citizens, thus local and governmental institutions are involved in managing sport facilities, logistics, road conditions, and the liveable spaces that enable the team to carry out matches, for the citizen's direct and mediated enjoyment.

In the following paragraphs we propose an interpretative and dynamic mapping of the main primary stakeholders that in different ways interact with the football club in Florence. The fulcrum of our analysis is the fan community that we will analyse both in socio-demographic and organisational terms.

\subsection{Customers: the "Viola" fans}

The "viola" ${ }^{\prime}$ are fans, spectators, supporters of the Fiorentina. These individuals can be considered customers of the football team's product, the first product being the emotional involvement experienced by attending the match.

Subscribers and spectators of the Fiorentina are a crucial support in producing the game and make it possible to deliver the sport event. They play a meaningful role in the value creation since fans are the "demand" and are able to drag along friends, colleagues, family, etc. to the games. Fans are real activators of potential demand.

Fans, as direct consumers of the service offered by the sport club (match), assume an important economic value since their satisfaction depends largely on football club revenues (tickets, merchandising, TV rights, etc.). In the case of the Fiorentina, single and season ticket sales are an important source of income and of continuous growth ${ }^{4}$, being $10 \%$ of the total football club revenue. This datum is further reinforced by the average percentage of stadium occupation, which in the $2008-2009$ season was $68 \%$ at the Fiorentina's home stadium in comparison to a national average of $59 \%$ of total capacity ${ }^{5}$. The ample live participation of fans is therefore one of the strengths of the Fiorentina. This means the football club must offer services and apply technical policies (purchase and transfer of players, type of game, etc.) that are able to satisfy fan expectations, especially those of the season ticket holders, who have the highest level of identification with the team.

\subsubsection{Socio-demographic features of the "viola" fans}

The Fiorentina fans can be considered a "tribe" of people who share the same passion for the Florence football team. The concept of community used in this research is that of "tribe" in the anthropological sense, rather than sociological or marketing sense (Muniz, O’Guinn 2001). The

\footnotetext{
${ }^{3}$ The term "viola" means "violet" i.e. a bluish-purple colour, and this is the colour of "la Fiorentina's" jerseys, hence the fans team formal name viola.

${ }^{4}$ Season ticket sales for the ACF Fiorentina raised more than 6 million euro in 2007-2008, then 8 million euro in 2008-2009. Poesio, E. (2009).'Poveri, ma belli'. Corriere della Sera, Venerdì 3 Luglio, pp. 10-11.

${ }^{5}$ See Lega, C. (2009), Analisi del trend degli spettatori allo stadio e degli ascolti televisivi della Serie A TIM e della Serie. B TIM, Maggio.
} 
territorial bonds among city, fans and team in this case are particularly important. One anthropological definition of a tribe is a "group of individuals united by a family bond and by the sharing of a territory". According to a sociological approach, Maffesoli (1988) uses the metaphor of the "post-modern tribe" to point out "micro-groups of people that share an affective drive". In the case of the Fiorentina, this is a tribe of people who are passionate about a football team. Nevertheless, while some "historical" football teams such as Milan, Inter, Barcellona, etc. have fans and supporters pluri-localized, the case of viola fans is atypical and special: they are a "group of people geographically marked".

Research into the Fiorentina's season ticket holder database (Zagnoli, Fanti, Radicchi, Lamanna 2004) indicates a strong "viola" collective identity that underlines the relevant territorial origin of membership ticket holder fans. Of these, $50 \%$ live in the city of Florence, with a further $37 \%$ located in the Florentine metropolitan area. Thus, this overall $87 \%$ of membership-subscribers confirms the very strong territorial tie existing between the fans and the team (figure 2). This also implies that the stadium can easily be reached by many supporters using bicycles, scooters or even on foot, making it handy and immediate.

The strong identification between Florence and its football team is confirmed by a high number of subscriptions purchased every year by Florentines. In the 2007-2008 ${ }^{6}$ season, there were 22,856 subscribers to ACF Fiorentina, a value pretty much confirmed as a trend for the last seasons ${ }^{7}$, making the Fiorentina one of the top 5 teams for maximum number of subscriptions sold ${ }^{8}$.

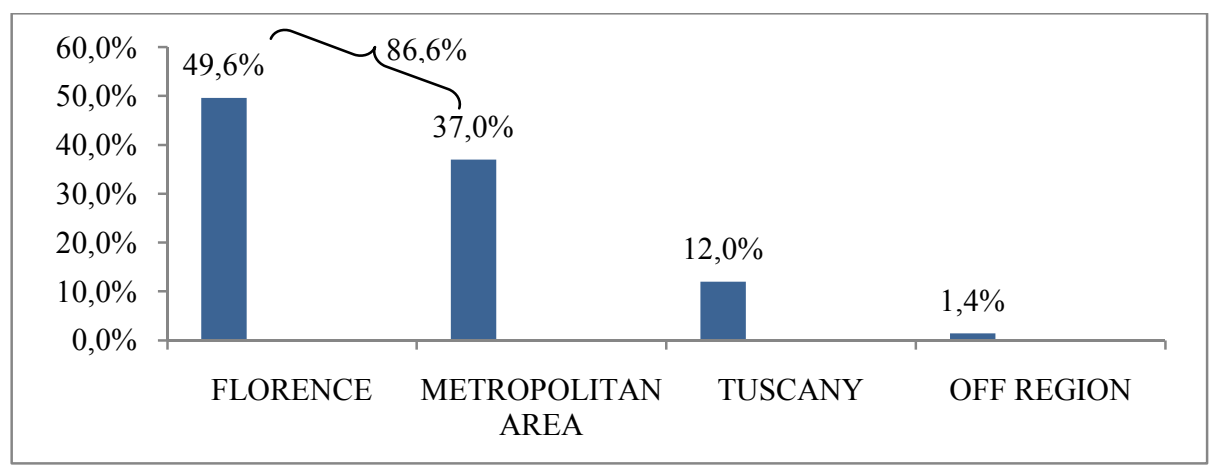

Figure 2. The strong collective "viola" identity

The bond between Florence and its football team has always been very strong: even when the team down-graded to Division C2 followed to the bankruptcy in the 2001-2002 season, the number of supporters and membership season ticket holders remained that of when it was in the First Division, with about 17,000 subscribers. The collective viola identity emerges even in the current "turbulent" football environment as well: notwithstanding sporadic episodes of violence, increase in average ticket prices, alternative viewing choices for enjoying sports events (digital TV, Internet, etc.) and the continuous change in the schedule of games ${ }^{6}$, the "active" participation of fans remains stable and relevant.

Fans are predominantly male, aged between 25 and 44, who have supported the "Viola" for a long time ${ }^{7}$, and can be divided into three socio-demographic profiles: the core fans, young people and seniors. Most of the "core group" (25-44 years) are males, live in Florence or in the metropolitan area, and belong to the middle-class. They have a high-school diploma and are white-collar workers. Many of these supporters choose a particular sector of the stadium (the Curva Fiesole) ${ }^{8}$. This means not only "watching" the match but also engaging in the role of supporters who incite their team.

\footnotetext{
${ }^{6}$ Several years ago the Serie A has been "split" throughout the weekend: besides Saturday and Sunday afternoon matches, there are two games on Saturday (at $6 \mathrm{pm}$ and at $8.30 \mathrm{pm}$ ) and a Sunday night match (at $8.30 \mathrm{pm}$ ).

${ }^{7}$ There are entire generations of Viola membership subscribers: grandfathers, fathers, sons and grandchildren.

${ }^{8}$ Curva Fiesole is the place to be for chants, songs, drums, and non-stop team support; thus it is the area in the stadium where most young people are found.
} 
"Young people" (6-24 years) (students, apprentices, etc.) have a presence "en masse" in the Curva Fiesole, the sector of the stadium with the liveliest fans who have a desire to join in and share the team's fortunes, emulate and admire the "more expert" and better known supporters, and be part of the historical groups of the "Curva" sector.

"Seniors" (over 44 years), due to their mature age, tend to watch the game itself carefully rather than seek an active participation in supporting activities. They are more interested in comfort and safety; hence they are likely to occupy the "quiet" seats of the stadium like Maratona and Tribuna.

The socio-cultural level of fans is predominantly middle class $^{9}$ thus confirming that football is a mass sport. Nevertheless, the viola fans social status seems to reflect the city's socially productive sector: workers, students, entrepreneurs, merchants, etc. who have an active role with the Fiorentina, who are considered by everyone as common "property".

The structure of the fan community on the whole appears varied, encompassing those with very great or lesser degrees of "fanaticism"; those who enjoy going to bars ${ }^{10}$ or a recreational facility; and those who are affiliated with a fan club.

The dimensions and attributes of the Viola fan community make it a remarkable phenomenon in the local context. On the occasion of every match, the team can count on about 45,000 spectators between the real and the mass-media audience. The most relevant segment are the membership subscribers (around 23,000 in the 2008-2009 season) who express their loyalty to the team through live participation in all home games as well as many out-of-town games. There are about 9,000 live spectators at home matches ${ }^{11}$. There are about 9,000 media spectators who watch the matches on Sky television (satellite pay-TV), which broadcasts every game of the Fiorentina ${ }^{12}$ as well. Since 2007 the games are even broadcast by digital terrestrial TV at half the price of Sky, and the estimated audience is around 8,000 spectators $^{13}$. There are also many enthusiastic fans who neither frequently go to the stadium nor watch the games on television, but who do demonstrate an interest in the team's fortunes by reading newspapers and "posters", and numerically this might involve a great part of the local population. Even if they are not interested in football, they feel represented by the team and involved in its successes and failures. The fan community is further expanded if we consider the grassroots football schools and youth sectors connected to the team that constitute a sort of local "breeding ground", not only for the next champions, but also for growing fans. The Fiorentina team in Florence seems therefore to be the only one "event" able to mobilize, more or less simultaneously, the interest of tens of thousands of people since fans share their passion with families, friends, colleagues, etc., thus making the team a meaningful expression of the city.

\subsubsection{Fans organisational structure: the Viola Clubs}

When analyzing the manifold components that constitute the viola fan community, the first to emerge is an ample group of "organised" fans or members of the so-called "Viola Club". As a whole, the structure of the supporter's community appears as a variegated and composite network of microgroups, a sort of "tribal constellation" (Cova 1997) (figure 3).

\footnotetext{
${ }^{9}$ The number of subscribers that hold a university degree is lower than those with a high school diploma and of a middle-school certificate.

${ }^{10}$ The "Bar Marisa", located near the Artemio Franchi stadium, is where traditionally young and senior Fiorentina supporters meet up to discuss matches results, technical aspects of the team, players performance, etc.

${ }^{11}$ Average number of live spending spectators for each match. Source: Lega Calcio, 2009.

${ }^{12}$ Average number of Sky spectators for each match. Source: Lega Calcio, 2009.

${ }^{13}$ Mediaset Premium broadcasts Champions League matches, while Dahlia TV offers a full package with all the Fiorentina home and away games.
} 
Although there are some national and international fan clubs, i.e. Scandinavia, Malta, etc., most of the population of Viola Clubs is rooted in the Florence metropolitan area, confirming the identity between the city and the fans.

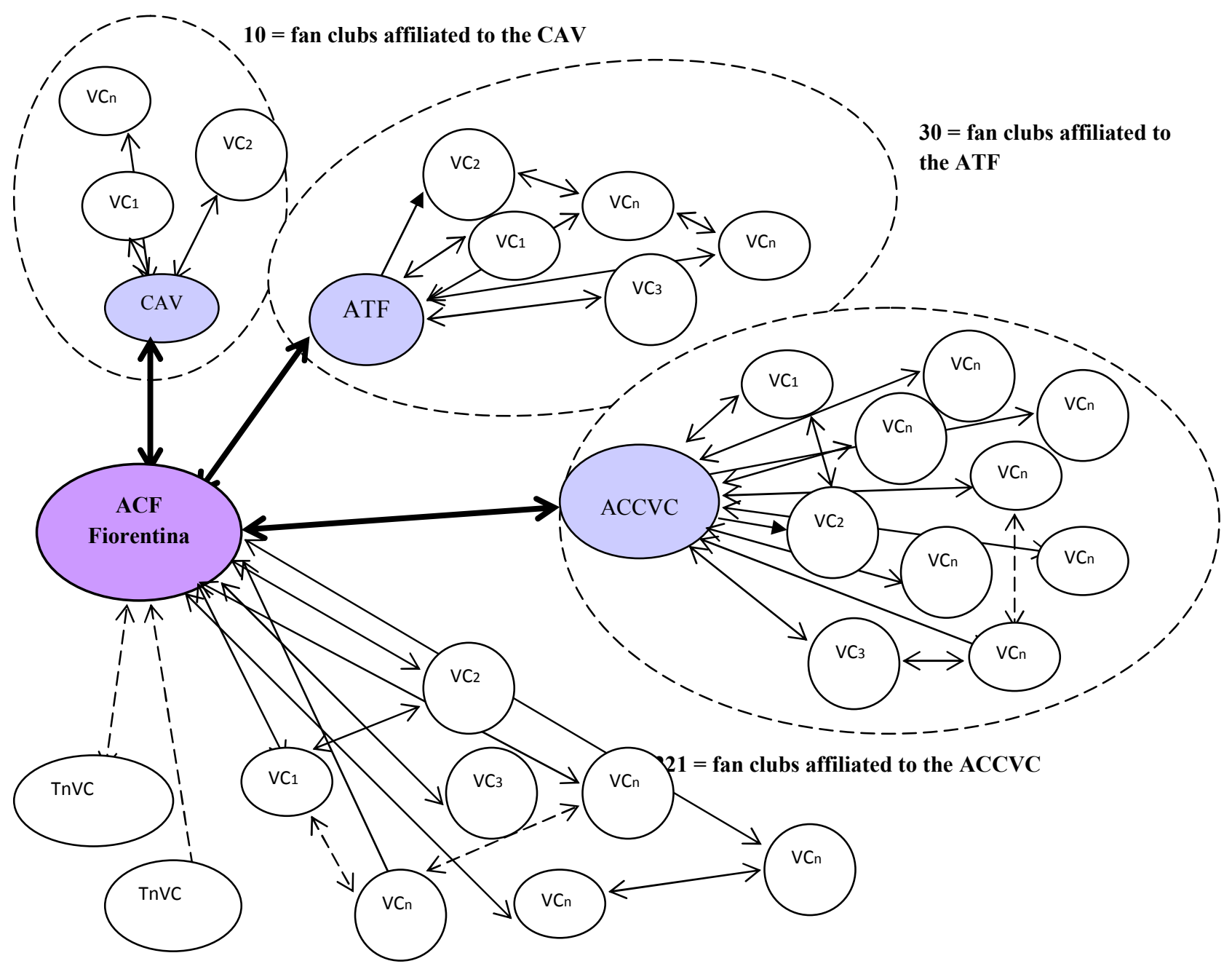

Supporters not affiliated to a Viola Club

“Autonomous Viola Club"

$\mathrm{CAV}=$ Collettivo Autonomo Viola

$\mathrm{ATF}=$ Associazione Tifosi Fiorentini

ACCVC $=$ Associazione Centro Coordinamento Viola Club

Figure 3. The ACF Fiorentina fan community organisational structure

Some Viola Clubs act autonomously. There are historical groups that for a long time have done their activities (single tickets and season tickets selling, web sites, house organ dedicated to the supporters, etc.) without having higher co-ordination, such as the "Settebello", founded in 1965. The autonomous Viola Clubs segment is quite small. The attitude of Fiorentina fans is therefore that of collaboration, "playing together" to achieve the success and continuity of the city team.

Many fan clubs of the Fiorentina are affiliated with associations that have an active supportive role in the policies of the football club. The most important Viola club associations are the Centro Coordinamento Viola Club (ACCVC), which includes around 220 clubs; the Associazione Tifosi Fiorentini (ATF) with 30 fan clubs; and the Collettivo Autonomo Viola (CAV) that includes about 10 clubs specifically located on the Curva Fiesole. The size of Viola Clubs can vary from 20-30 people to more than 500. If we hypothesize that the average number of fans enrolled within a single fan club is around 180-200 supporters, these create a community of fans affiliated to a Viola Club that accounts for about 50,000 people. Of these, a remarkable number are membership subscribers as well $(23,000)$. 
Others are fans of the Fiorentina who may not have a season ticket, due to not living in Tuscany or being residents in another country, but they express their own attachment to the team through membership in a fan club, where they can share with others their enthusiasm for the Viola.

The Fiorentina is aware of the importance of having good collaborative relationships with fan clubs: the representatives of the three main associations are often guests at official meetings, congresses, press conferences, operational groups for security (GOS), etc., to express their own point of view regarding decisions that concern the football club not only on technical terms, but also strategic and managerial (i.e. facilities management, training fields, out-of-town game management, etc. $)^{14}$.

Figure 3 shows the affiliation of each Viola Club to a higher organization; hence the connections among these actors are illustrated. The Viola Club associations have many activities for single fan clubs that can be grouped as follows:

- support of home game tickets and membership subscription selling,

- support of out-of-town game ticket selling and the organization of packages (ticket+journey) for members who want to go to the match venue or even stay abroad for longer,

- organization and management of the typical supporter activities in the stadium, like banners, chants, drums, choreographies, etc,

- support of start-up Viola Clubs and growth implementation,

- management of the communication process, including information distribution, to fans through the use both of new technologies (mobile phones and web sites) and traditional tools (i.e. magazines of the association of Viola Club ${ }^{15}$,

- production and commercialization of "non-official" merchandising. Even though a good percentage of supporters buy the Fiorentina material, only $30 \%$ of those fans purchase official merchandise. The fans feel "closer" to the gadgets (i.e. scarfs, hats, hanging keys, etc.) offered by the Viola $\mathrm{Club}^{16}$,

- carrying out convivial and "social" activities in the area, such as organizing parties, billiards and bowling tournaments, besides the management of five football fields and the athletic activities for children, with evident commitment to the local community.

Besides their coordination of a Viola Club, fan club associations play a crucial role in the support of the team in addition to the mere sport itself, as happened on the occasion of the economic failure of the football club. The rebirth of the Fiorentina occurred thanks to the strong stimulus of local citizens ${ }^{17}$ started by a small group of fans and supporters belonging to the main Viola Clubs, who became directly involved in the negotiations for the football club, and pressured the appropriate institutions $^{18}$.

\footnotetext{
${ }^{14}$ The Operational Group for Security (GOS) includes representatives of the police, local municipality, fire department, health service, besides representatives of the guest team and local fan clubs.

${ }^{15}$ For example, the ACCVC, one of the most well organised supporters associations, has implemented an SMS service to communicate in real time with all the Viola Club Chairmen. This service enables each club to be upto-date on changes of instructions, new services and general meetings of the Association.

${ }^{16}$ Some fan clubs have registered a trademark - the Indiano - expression of the Curva Fiesole clubs, to be placed on their merchandise. In this case the Viola Club seem to provide for the football club deficit, by offering products and gadgets that satisfy the particular needs of fans, first and foremost, with regard to the price.

${ }^{17}$ During the months before the football club's failure, through the local press and other media, fans succeeded in informing the whole city about the financial crash Fiorentina was heading for. They also organised initiatives aimed at increasing the level of protest, such as the famous torchlight procession of April 2001 on the streets of the city centre which involved over 30,000 fans, or by boycotting season ticket subscriptions, and so on.

${ }^{18}$ Lawsuits contemplated by some representatives of Viola Clubs have been central in expressing their disagreement with the decisions made by the Florentine Court, the FIGC and the Lega Calcio. Those acts were aimed at speaking out against a "sick" football system widespread among many professional teams that were not penalized as Fiorentina was.
} 
Despite the importance of the Viola fan organizations, the number of supporters who are not members of a Viola Club is high. These participate in the team's activities by going to the stadium, following matches on $\mathrm{TV}$, and staying informed about sport results through the press.

\subsection{Players, fans and coach}

Over the years the relationship between players and viola fans have changed, becoming quite "atypical" in comparison to the national football scene. In the 80s many players had strong ties with the team since they were from Florence ${ }^{19}$. In the ' 90 s good players stimulated fan participation, although they were not "local" or even from other countries ${ }^{20}$. Nevertheless, only a few players have manifested a strong attachment to the "team colours". Very often, since they were young training players, they "abandoned" the Fiorentina to play for other football teams. This made viola fans think that those players were sort of "mercenaries". Viola supporters then started identifying strongly only with the team as a whole, even though they are enthusiastic about the athletes who play on the team. Fans thus express an explicit attachment to the "viola jersey" and confirm their identification not with the players but rather with the team of their city.

The bond between viola fans and the coach is also rather special. Cesare Prandelli, who has coached the team since the 2005-2006 season, has succeeded in positioning the Fiorentina at a very high level $^{21}$, by overcoming the competitive stall phase that countersigned the team before his arrival ${ }^{22}$. The positive performance is strengthened by the coach's personality, a leader with style, yet without excess. Prandelli is in fact a well-balanced person both on and off the field. Even in victory he never loses his fair play. Fans listen to the coach, respect him and even revere him $^{23}$ helping over time to make the viola fan community a "model" of civilization and fair play. Consider as an example the introduction of a sort of "third half" promoted in Italian football by the ACF Fiorentina: it is a sportsmanlike gesture that tries to unite winners and losers ${ }^{24}$. An important role of the coach as "catalyst" towards the fans emerges: the coach, the main promoter of the initiative, succeeds in stimulating the supporters to be spokesmen of a message of respect and civilization, thus confirming a strong civic sense on the part of Florentines.

\subsection{Ownership}

The ownership of the Fiorentina team changed one after the other until the failure in 2002, but was always characterised by a strong local connection ${ }^{25}$. During the 80 s, the Pontello family, well-known

\footnotetext{
${ }^{19}$ For example, Antognoni, Galli, etc.

${ }^{20}$ For example, the Argentine champion Gabriel Batistuta and the Portuguese Rui Costa.

${ }^{21}$ In four years the team classified at the fourth (2005-2006), third (2006-2007) and fourth position (2007-2008; 2008-2009).

${ }^{22}$ Even though Fiorentina did not win any Cup or tournament, considering its economic potential compared to those of its competitors, recent sports results are significant: in the Italian football championship AC Milan, AS Roma, Internazionale FC and Juventus FC are the top clubs in terms of revenues with respectively 209.5, 175.4, 172.9 and 168 million euro, while ACF Fiorentina revenue amounts to about 100 million euro. Source: Lega Calcio, 2008.

${ }^{23}$ See"Viola" (2009), Magazine, Marzo p. 18-19.

${ }^{24}$ On 2 December 2007, after having been defeated 2-0 by the Internazionale FC during a home game at the Artemio Franchi stadium, the Fiorentina coach and players reacted sportingly, applauding and giving handshakes to their (victorious) opponents. The Lega Calcio, after initial perplexity, decided to extend this habit to all professional and amateur football clubs beginning with the 2008-2009 season.

${ }^{25}$ After bankruptcy hit former owner Cecchi Gori on 1 August 2002, AC Fiorentina also failed. The same day, in light of several initiatives, demonstrations, and sit-ins by the supporters and local citizens during the previous weeks, the mayor and the sport councilor of Florence, following the FIGC resolution allowing "expression" of a team representing the city, founded a new football club: Fiorentina 1926-Florentia Srl, with the mayor as president. In the following days, the football club was transferred to a new owner, businessman Diego Della
} 
Florentine builders, owned the team, and in the ' 90 s the owner was the Cecchi Gori family, involved in the field of cinematography. These ownerships featured the Fiorentina as a focal organization deeply rooted in the local context, an expression of the Florentine imprinting. Following the failure of the football club and its rebirth in 2002, the team went to the well known Italian entrepreneur Della Valle, for the first time ever a "non-Florentine" owner. Although local ownership is a fundamental dimension for fans since it is an expression of their identity with the city and the team, at the time of the crisis the arrival of a new non-local owner as a "rescuer" did not generate any disagreement among supporters, since this solution was the only possible way to save the team and to return it to its fans. Although not Florentine, the new owner won support for his operational, technical and business choices. He started a process of creating collaborative relationships in the city, among supporters, institutions and the football team. The new owner, who was an entrepreneur in the fashion leather sector, found an image and marketing connection between his products located in the luxury market and the tradition of quality and elegance of Florentine fashion. The team also had to achieve a role of first class, and therefore quickly up-graded its position and returned to the First Division.

\subsection{Local community: the city of Florence and its citizens}

Football is the most popular sport in Florence and "La Fiorentina" is the only team. In terms of football, Florence is a monochromatic city: "viola". For inhabitants of this principal Tuscan town, being Florentine is doubtlessly a source of great pride, and their love for Florence is identified with the football team and vice versa. Even those who do not go to the stadium consider the team to be communal "property", indicating a strong and unusual process of identification compared to other football contexts ${ }^{26}$. The city shares the victories, joys and sorrows of the team. Especially during times of crisis, such as the failure of the football club, citizens have remained loyal to the team by developing a real collective emotional mobilization ${ }^{27}$ (Le Bon 2007): even in adversity the participation, support and the identification of the citizens with the Fiorentina contribute to strengthen the "viola collective identity" of the city with its team. The local community therefore is an important intangible resource for the football club: the strong collective identity with the team, the cohesion of the city even in sportive and corporate adversity, favor the survival and growth of the football team with ample local support.

\subsection{Local administration and institutions}

Besides playing a meaningful role in terms of sport facilities concessions - football stadiums are public property in Italy, in this case the Municipality of Florence owns the "Artemio Franchi" stadium, granting use to the Fiorentina - local administrations have a further function in supporting the football team. For example, when the football club failed, the numerous and pressing solicitations derived not only from fans but from the whole citizenship and Municipality (Mayor and Sport Councillor of the city of Florence) played a mediating role with the sport judicial authorities (Tar and $\mathrm{FIGC}^{28}$ ) to save the Fiorentina, the "heritage" of the local community.

The relationship between institutions, especially those in charge of maintaining public order, and the supporters is particularly interesting. The collaboration among the police, local administration,

\footnotetext{
Valle.

${ }^{26}$ Benassai, D. (1998). Firenze: un amore viola (p. 68). Firenze: Edizioni Scramasax.

${ }^{27}$ For example consider the change of the football club name that, after going bankrupt in 2002, became "Florentia Viola". For the first time ever the traditional name of the club, "AC Fiorentina", the expression of the team's history and the local context, was changed to fulfil legal matters. The active participation of fans and the whole local community has influenced the new owner's decisions. In 2003 Della Valle took part in an auction to purchase the former football club assets. He purchased the historical "brand" of the club in addition to its social colours. In this way he guaranteed, at least in name, the continuity of Florence team history.

${ }^{28}$ Federazione Italiana Giuoco Calcio (FIGC).
} 
universities, and football club to actively involve fans was crucial ${ }^{29}$. The aim was to overcome repression and control, and to stimulate the co-participation of all the stakeholders involved. For example the city is an ideal context for the experimental application of the fans' card $^{30}$. Supporters especially recognize themselves in the role of stakeholder by being directly involved in the strategic decisions of the football club and institutions, partly due to dialogue with the chief of police, with his long experience in managing conflicts, safety matters and sport supporters ${ }^{31}$. Moreover, the legislation regarding stadium security, among other aspects, strongly limits use of banners. This hence "inhibits" the possibility of argumentation and wit typical of the Florentine fan that were expressed through the banners. Without the opportunity of expressing their "feelings" for the team, many viola supporters are now particularly favourable to the introduction of the fan card so they can express their loyalty to the "viola" 32 .

\subsection{Sponsor and suppliers}

The Fiorentina football club shows a certain weakness in terms of its functional managerial structure. The marketing area has only recently been developed; therefore suppliers and sponsorship contracts have been managed more pragmatically than strategically. Sponsors and suppliers are important stakeholders able to confirm the image of the football club with citizens and customers. They also enable the team to offer to fans important economic and service support. Certainly Toyota, the main sponsor, is consistent with product positioning, by being reliable and placed in the middle segment of the market. Those values are consistent with the positioning strategy of the Fiorentina. Moreover the local bank Cassa di Risparmio di Firenze has with the Fiorentina jointly promoted a credit card specifically dedicated for the viola fans ${ }^{33}$. This co-marketing strategy on one hand can increase viola fan loyalty. On the other hand, through information gathered about each credit card subscriber, the football club can enrich its supporter database in order to better respond to the fans/users. Additionally, the bank can be "proud" of being the main financial partner of the "beloved team".

In spite of the important potential that they can express, the football club appears to have a poorly developed strategy that would enable suppliers and sponsors to be involved in a mutually virtuous circle. Until now, those actors have played a minor and underdeveloped role, unlike other football clubs.

\subsection{Media}

The media foment the existing strong interest in the Fiorentina by conveying information to fans at all levels ${ }^{34}$. First of all, if local "posters" or daily newspapers report positive news on football results,

\footnotetext{
${ }^{29}$ Over the last years, professors, researchers and students of the Master's Degree in Sport Management have collaborated in several projects such as the proposal of a "stadium without barriers", the fan card's experimental application in Florence, in addition to organization of seminars and workshops about the sport events safety and security.

${ }^{30}$ The football fan card, launched in 2004 by the Italian "Osservatorio Nazionale sulle Manifestazioni Sportive" of the Interior Ministry, was born by being aware that sport and football events safety and security cannot be a part of effective organisational measures to prevent violence episodes that not only required repression. The fan card enabled the tracing of single fan participation in different sport contexts.

${ }^{31} \mathrm{He}$ is a former President of the Italian “Osservatorio Nazionale sulle Manifestazioni Sportive”.

${ }^{32}$ See Prandelli, N. (2008). La tessera del tifoso tra vincolo e opportunità: il caso della ACF Fiorentina. Università di Firenze, Novembre.

${ }^{33}$ The so called "Viola Card".

${ }^{34}$ The centrality of new media influences the sports products offered by changing the rules of some disciplines. This even influences the ways fans and spectators enjoy a football match. The change in scheduling of games influences habits of supporters with ever-increasing choices to enjoy football events many times a week. See Zagnoli, P., Radicchi, E. (2008). Sport Marketing. Il nuovo ruolo della comunicazione. Milano: Franco Angeli.
} 
agreements on the purchase of important players, or of the team's victory, the day of the Florentines will seem positively different. However, negative football news also slightly influences the humor of Florentine citizens and families. Second, television (especially) and the other local press are able to transform the football match and other Fiorentina matters (victories, defeats, players purchase and transfer, the coach's opinions, the building of the new stadium, etc.) into an event discussed seven days a week. Fans and supporters, facing a sort of news "bombardment" which is often diametrically opposed, barely have time to reflect and arrive at their own opinion ${ }^{35}$. The exponential growth of written and spoken communication has allowed viola supporters to suffer a sort of overdose of information (Da Empoli 2002), whose main content is often the importance of a successful result at all costs. This process in some cases has a negative impact on team performance, besides producing a misunderstanding between the owners and the fans. The particular mood that characterises the local press in Florence sometimes has strongly "disturbed" the Fiorentina in carrying out its "normal" sport activity, thus destabilizing football club planning

Moreover, the media centrality further exaggerates the importance of some news assumed by the football team in Florence. The attention of local daily press, radio and television is almost exclusively focused on the team and on the relationships developed around it. This can damage the other local sports disciplines such as rugby, which become second class in terms of institutional decisions about the concession of city sport spaces and facilities.

\section{The social network of ACF Fiorentina}

In attempting to place the fan community within a network of relations where it operates using different strategies and adopting different policies, network analysis can be used (Håkansson, Snehota 1995, Gummesson 2006, Mitchell et al. 1997, Scott 2000, 2003, Wasserman, Faust 1994).

The "structure" of the network is characterised by a multidirectional set of relations (polyadic network) (Freeman et al. 1992). In fact, one may observe the presence of a multiplicity of stakeholders (nodes) interacting with each other, such as the team, the fans, the institutions, the media, the owners, etc., to contribute to providing the sports service (figure 4$)^{37}$.

Overall the network appears to be relatively "dense" (Burt 1983, Galaskiewicz 1979, Rowley 1997, Scott 2000, 2003) since each stakeholder sets up interactions with all the other members of the community $^{38}$. The provision of the sports service implies the co-participation of multiple actors engaged in various ways in the organisation of the sports event, which in the case of football, takes place frequently.

Despite each team, and the Fiorentina as a case in point, being an actor positioned ab origine at the core of the system (figure 4), the relational "centrality" of a stakeholder may be measured in terms of power, management of relations, specific importance within the network, etc. (Burt 1982) ${ }^{39}$.

\footnotetext{
${ }^{35}$ See Coppini, A. (2009). L'informazione e l'eccesso di comunicazione: ostacoli immateriali e fisici alla realizzazione dello stadio senza barriere. Il caso Firenze e ACF Fiorentina. Università di Firenze, Aprile.

${ }^{36}$ For example consider the tension that occurred during the 2008-2009 season between the local press and the football club, culminating with the coach announcing that he might leave the football team. He explicitly threatened to interrupt his coaching because of some media news regarding his technical choices. In his opinion those press articles were "unbalanced, schizophrenic and auto-destructive". See Bardazzi, L. (2009). 'Firenze è autodistruttiva. Il mio futuro è in dubbio'. Corriere della Sera, 1 Marzo.

${ }^{37}$ The graphic representation of the network is the result of qualitative analysis without the use of specific statistical software. The connections between focal organisations and stakeholders were developed by interpreting the results of interviews and discussion groups.

${ }^{38}$ Network density is the extent to which all actors in the network are connected. It describes the general level of linkage among members and measures the ratio of the number of ties that exist in the network to the number of possible ties, if each network member were tied to every other member (Scott 2000).

${ }^{39}$ Network centrality refers to an individual actor's position in the network relative to others. Centrality measures the extent to which communication within a network passes through an actor. Network centrality refers to power obtained through the network's structure (Rowley 1997).
} 


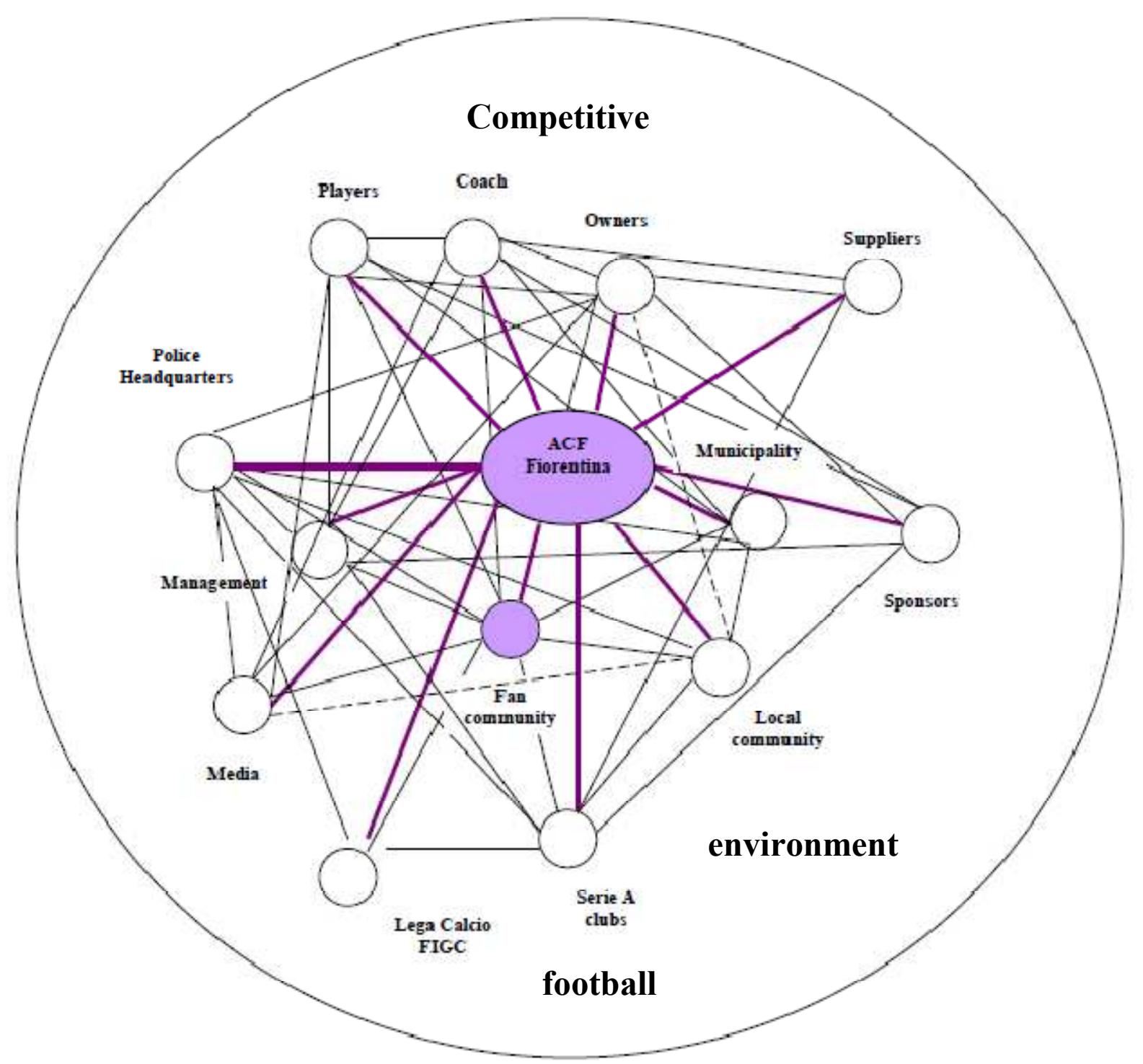

The continuous lines connecting the various stakeholders involved in the network show the existence of a collaborative relationship between the same. When the line is "thicker" this means a stronger collaboration between two stakeholders.

- - The dotted lines show a lack of collaboration between the actors of the network.

Figure 4. The social network of ACF Fiorentina

Using the concept of "closeness" (Rowley 1997), that is, the extent to which one stakeholder is able to "independently" activate connections with the other members of the network, we can define the fan community of Fiorentina as a central stakeholder. With regards to events that maintain a fan's interest in the club, such as the dynamics of player transfers, the introduction of the fan card, the building of a new stadium, etc., Fiorentina fans play an active role in the network, relating directly to the football club owners and local institutions and expressing their opinion both "officially" (press releases, open letters, etc.) and "diffusely" (intervening in the many local sports transmissions, blogs, online articles published on the net, etc.).

Regarding interaction within the network, the fan community is particularly "opinionated", putting pressure not only on other stakeholders, first and foremost institutions and the local community, but even in some cases, considerably influencing the football club's strategic choices. But the fan community strongly identifies with the team, and in the effort to maintain this identification, is open to dialogue and to collaboration, constantly pressing the owners to improve the team's technicalcompetitive qualities. The ownership and management are thereby forced to assume a position that 
involves the fans and negotiates with them, asserting their role as protagonists of the city and therefore of its football, which in Florence is based on the strong ties between the football club, team of players, fans and institutions. A virtuous circle is thus created wherein, thanks to the collaboration of the various stakeholders, and in part induced by relations of power, the entire local context pivots on the value created.

The case studied enables us to identify, as well as the variables used in literature, and to delineate a network (density, centrality, etc.), in which further dimensions seem to influence the structure of the specific ACF Fiorentina system and the relations between the stakeholders who compose it.

One variable, decisive in structural terms, is the territory, with the cultural aspects, values and principles which have, over time, instilled themselves in the people inhabiting a specific local context.

The high level of interpenetration between the local environment, specific features of the territory, and of civil society affects people's behaviour, delineating a largely atypical network structure compared to other networks of actors in the sports sector. For example, in terms of fan behaviour, social exclusion and juvenile unease seem to be relatively limited phenomena at a regional level (Istat 2008), so that the absence of forms of "social deviation" throughout the territory may explain the almost total absence of violence among Fiorentina fans.

The fans' tendency to continuously challenge the football club and institutions to "fight" for something which they feel is theirs derives from the "Florentine outlook" which "enjoys a verbal scuffle and manifest dissent, which is diffident, suspicious, ever inclined to believe that someone wants to rip them off",40 and therefore ready to "shout" its opinion at anyone attempting to lay their hands on its heritage, whether the city itself, a monument, or football club.

On the sports side, a close connection emerges between Florence's social and economic features and the structure of the local football system. Florence has always played a leading role in the western world in artistic, cultural, and scientific terms. The football club, the fans and the people want the performance of the football team to reflect the same level of excellence, yet victory entails a high cost. In the case of Fiorentina this was accompanied by an economic situation that built up until 2007 and involved purchasing "free transfer" players ${ }^{41}$. The team is composed of young players who express themselves to their best and can sometimes pull off significant results but who are unlikely to guarantee sufficiently constant performance to aim for the Cup since still in a development phase ${ }^{42}$.

The situation of Fiorentina must be interpreted in the light of the Tuscan social-economic context, a region characterised by a dense network of medium-sized cities and which compared to other Italian regions has undergone a process of "light industrialisation" (Becattini 1975) placing it in a "peripheral" economic position. Top class clubs like Milan, Inter FC, Juventus, etc. are able to create top-performing teams not just because of the considerable financial resources provided by selling TV rights but also because large industrial groups back them, allowing them to afford to buy champion players and ensure organised and efficient technical management. In the case of Fiorentina, despite the owners being a business group at the higher end of the leather goods market, they are still a family firm, an expression of the economy of the "third Italy" (Bagnasco 1977) characterised by the predominance of a system of small to medium-sized enterprises far from the process of economic development typical of historically industrialised regions such as Lombardy, Piedmont and Veneto.

In addition, the strictly "local" nature of the supporters while on the one hand constituting a strong point, as they are able to mobilise the entire city in moments of team difficulty, on the other hand this factor reduces its "appeal" to television networks. It has almost exclusively local popularity,

\footnotetext{
${ }^{40}$ Taken from the blog of a Fiorentina fan. See http://blog.libero.it/archiaraviola/5735501.html.

${ }^{41}$ However, after participating in 2008 and 2009 in the Champions League and especially after selling the Brazilian player Felipe Melo to Juventus for 25 million euro, the club now has assets of several tens of thousands of euro, not yet reinvested in new players.

${ }^{42}$ Fiorentina won its last cup thirty years ago, in 1969.
} 
and the discontinuity of the game makes the Fiorentina a "minor" team in terms of audience, preventing it from negotiating consistent fees for broadcasting matches and denying it the significant resources needed to purchase top coached and players ${ }^{43}$.

There is therefore a discrepancy between the perceived position of the club at a national and international level and its locally desired "status": the city would like to see its team among the top teams but comes up against a competitive, external environment dominated by the big teams with higher skills and resources. The continual gap between top-level competitive goals on one hand, and strategic and economic restraints on the other affects the structure and relations within the network via the constant dialogue between fans, institutions, media, and the football club which keeps the network of relations alive at a local level.

The dominant driving force in the Fiorentina network is the will to win. External competition triggers co-operative interaction of the various actors: the competitive commitment of the coach and players, economic investments by the owners, fan support for the team, institutional commitment to ensuring the correct use of local facilities and logistical resources. Subsequent to going bankrupt in 2002, an unusual situation has arisen in which the stakeholders have behaved according to network logic, aiming to ensure the success and continuity of the team.

Despite the absence of star players, the co-operative boost of the coach, owners, sports director and management has led to important results being achieved. This specific moment in time therefore sees each stakeholder acting as part of a network with a strong local and sports identity in which each plays their role. The competitive strategy of Fiorentina over recent years has been to pursue ambitious goals (such as achieving classification in the Champions League) of an intermediate level in relation to the financial and economic resources available, valorising to the utmost the resources of each individual stakeholder. This strategy has been adapted to external circumstances, shaping the football club's abilities to the competitive environment. At this moment in time the distinctive capability of Fiorentina has been its ability to create a single project in which the owners, players, coach, fans and institutions collaborate. It is a skill difficult for other clubs to match given that it is a specific expression of the local Florentine identity.

The viola fan community sees the team as part of its cultural, historic and artistic heritage. Not only does it respect the team but it plays a role as central stakeholder helping to create value through commitment and social participation which seem, given the results achieved, to compensate the discontinuity of technical performance and the scarcity of economic and financial resources.

\subsection{Towards a typology of sports fans' roles and behaviour}

In light of the empirical evidence gathered, we have proposed a first typology of fans' roles and strategies to add to current analysis that classifies fan behaviour with reference only to the sports event itself (Harada et al. 2009, Hunt et al. 1999, Kozanli, Samiei 2007, Tapp, Clowes 2002). This paper analyses the fan community not only to show the roles assumed by fans at the stadium, but above all to underline the variety of ways in which fans behave as stakeholders of their own team.

To represent fans' roles and behaviour, we have built a simple matrix (figure 5) where on the ordinate axis we put the variable "fans' level of identification with the team", while on the abscissa the "type of participation in the event".

Fan identification is defined as "the personal commitment and emotional involvement people have with a sports organization" (Sutton, McDonald, Milne 1997) and can be highly varied in degree (Fin, Giulianotti, 2001; Sutton, McDonald, Milne 1997): from low levels of participation (low) when

\footnotetext{
${ }^{43}$ By way of comparison, the signing budget of a team such as Inter FC, considered among the top international and national clubs is about 150 million euro a year and the coach Mourinho's salary is about 8 million euro net per season. In the case of Fiorentina, the annual signing budget is about 35 million euro and the coach Prandelli earns a net salary of slightly under 2 million euro. See http://www.legacalcio.it.
} 
the fan does not feel "part" of the club but is more interested in satisfying a need for entertainment, to an intense (high) level in which soccer identity subtends a common social identity that expresses the fan's affiliation to a sports club and/or to a specific local context.

Fan participation in the event can be direct or indirect. Real or live spectators are those who directly watch in the match, while indirect spectators enjoy the game through free-view television, digital, satellite and terrestrial television, radio, Internet and mobile phones. Sometimes the choice between direct or mediated participation seems to correlate to variable factors such as organisational (change in schedule of games), social (friends and family's influence), economic (increase in average ticket prices), distributive (ever-increasing "virtual" choices for enjoying sports events), technicalsportive (match location, team combination, refereeing), safety and security (episodes of violence occurring inside and outside stadiums).

Such factors can influence fans' choices to attend sports events. Moreover fans themselves in turn modify their participation by adopting broadly diversified behaviour depending on the intensity of identification and the "importance" of the match, apart from the various participation options compatibly with the timing of games, sport facilities and other commitments (work, family, etc.) (figure 5).

In terms of direct participation, live occasional spectators "consume" sport as with any other type of entertainment such as movies, music concerts, etc. In this group we can also include those people who go to the stadium sporadically to capture the "aesthetic" dimension of the event, the atmosphere and the "neat play" on the field.

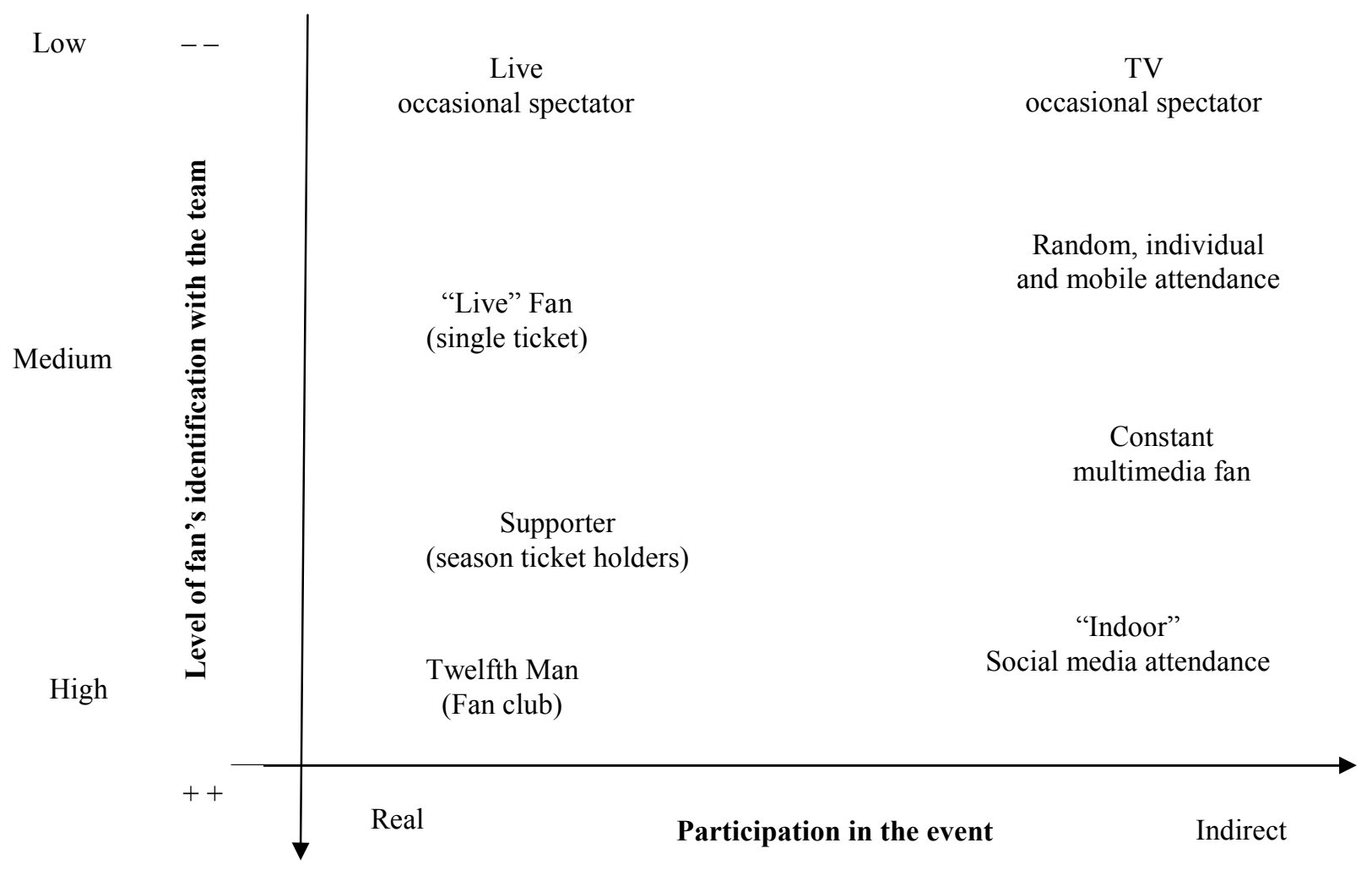

Figure 5. Fans' roles

For the live fan, participation in the event is not continuous, but motivated by the importance and the "drama" of each match. Live fans do not buy a season ticket. Their choice is guided each time in part depending on the "social" dimension: going to the stadium is a moment of aggregation with other people, friends, family, a way of having a good time together.

The supporter is not just a spectator, but "participates" in the event continuously by purchasing his season ticket to the home games. Despite following each match with excitement, the supporter is not an active member of the fan club, even though he feels highly motivated and part of the team. 
The "twelfth man", as the term suggests, is an essential support to the game and the success of the team as much as the players and coach are. The actions performed by fans during the game (ritual chants, songs, banner waving, etc.) motivate the team and "intimidate" the other side: fans' emotions, passions and moods can influence the result of the match. The "twelfth man" seems to actively and passionately follow every match, both home and away, in national championships and international tournaments. Fans truly believe they must "participate" in the game to "help the team win" 44 . What strengthens and distinguishes the role of the twelfth man compared to that of the supporters is the importance he gives to rituals, which he spends a great deal of his time in: planning celebratory routines, the wording to put on the banners, the songs to be chanted, co-ordinating the fan clubs. During pre-match days, fans meet up to discuss their "scenographic" strategies and keep themselves up-to-date with the line-ups of their own team and the opponents', as well as downloading online statistics on players' performances.

In terms of indirect participation, the growing use of new technologies is largely responsible for the reduction of live spectators ${ }^{45}$. Opportunities offered by the new media have modified fan behaviour in relation to how they enjoy a game, which for years characterised the sports culture rooted in our country.

Occasional TV spectators are those who watch on television the most important matches both at a national and international level (Champions League finals, European and World football championships, etc.). In this case the level of identification with a single team is quite low. What influences the type of participation is the passion for sport. Even when you do not have a "favourite team", the competitive spirit of football makes you "take sides". A spectator's motivation to be a fan of a club can be influenced by multiple intangible factors such as the popularity of a football player, the fame of a club, the passion for a specific "jersey", or other tangible aspects such as the country of origin of the teams competing on the pitch, the participation of star players, and the refereeing.

Within the segment random individual and mobile attendance we have classified sports fans that "sporadically" follow football mainly, though not exclusively, through web sites and mobile phones. Having a general interest for sport, they do not limit themselves to attending matches of a single team, but might download the most thrilling game highlights onto their laptops and/or phones. Fans included in this category often combine viewing the match with "live betting" services. In other words, create the possibility of betting on the broadcast event via streaming web sites or mobile phones. With new media, traditional "passive" participation in a football match is enriched by additional content which can be enjoyed wherever the spectator is, by maximizing his level of entertainment as being a football (content) and new media (tools) expert.

Constant multimedia fans create virtual communities of people with whom they can share their passion for the same team. These fans usually "attend" matches on pay-tv or through web sites that offer live football services. Through multimedia match attendance fans are not only able to follow their own team, but can even have real time exchanges of information with other fans, strengthening their own "ties" with the team. Despite a lack of direct participation, the use of new media can increase the fan's voice and the flow of information and comments, increasing the level of attention paid to the team.

The indoor social media attendance segment includes fans who usually meet up in small groups in public places like cafes, fan clubs, etc. or in friends' and families' houses for championship and Champions League matches and very often recreate a sort of "stadium atmosphere". Although they express a high sense of identification with the team, this group of fans prefers to attend the match by buying a seasonal membership card to a digital or satellite television network, mainly on account of

\footnotetext{
${ }^{44}$ As an example, consider some banners written by the Fiorentina fans for the Champions League match Fiorentina vs Liverpool", 29/10/2009: “Our faith is your strength"......"Fedelissimi"......"A unique city, a never ending love".

${ }^{45}$ See $\S .2 .7$.
} 
the increasing cost of live matches, the continuous schedule changes, the "distance" from the venue, etc.

The typology of roles proposed does not set out to be exhaustive, but provides some interpretative indications of the multiple combinations of fan behaviour in the light of empirical evidence. The representation of roles is not static. The positions (fans' role classification) assumed by fans are closely related to the strategies of the football club, both in technical and managerial terms, the role played by the owners, the competitive position of the team, the calendar of events, the media channels on which the sport content is provided (matches, interviews with players and coaches, dedicated channels, etc.), and to social and personal relationships (family, social class, income, etc.). Since success is what drives the popularity of a football club, a winning team can generally guarantee greater attendance in terms of fans and spectators. Fan loyalty is in fact a variable "depending" first and foremost on the success of a team.

Being included in important championships, achieving victories on the field, together with popularity, history, legend and the international flavour acquired over time by a team, are the prime factors influencing fan involvement. Nevertheless, the construction of a continuous club-supporters relationship aimed at preserving a certain level of fan loyalty and avoiding lower levels of identification and participation, is developed though the ability of each individual football club to undertake new sports-technical challenges and to set up initiatives able to involve the fans, such as modern management of football venues, an exciting team performance, appealing merchandising, the organization of collateral events, the offer of additional services (call centre, online services for fans such as games and chat, information services on mobile phones, etc.).

\subsection{Strategic postures of fans as a stakeholder}

In concluding this paper the need emerged to explore and offer a possible classification of strategies adopted by fans as stakeholders of a football club. Figure 6 was built by counterposing the fans' inclination to cooperate" with their "inclination to be a threat" to the football club and for the network as a whole. The analytical framework used here is that offered by the theoretical tools proposed by Freeman et al. (2007) to outline the strategic behaviour of a firm's stakeholders. The variables in Freeman's model (2007) - "relative cooperative potential" and "relative competitive threat" - can be applied to the fan community to delineate a first typology of fans' "strategic postures"; in other words, the different ways in which the latter are able to influence the decisions of the football club.

The graphic representation of figure 6 highlights a continuum of strategic behaviour: from maximum cooperation (partner) to dysfunctional behaviour.

Partners have very high cooperative potential, but at the same time may have great "control" over the football club's decisions and can therefore "shape" its strategic outcomes. Partners can be defined as "rule setters". These fans are particularly opinionated, able to direct their voice towards the football club. This can be done not only through open letters to the football club chairman and owners, press releases, speeches on local radio and TV (traditional media), blogs and web sites (new media), sit-ins involving the entire local community, etc. but also through direct contact with the football club's top management, coach, and local institutions.

Partners are generally an inner circle of fans who do not "speak" as individuals, but it is the fan club which interacts with the other stakeholders (football club, media, local government, etc.). Apart from their official duties of co-ordinating fans, supporting the team, and assisting the football club in managing ticket sales, fan clubs over the years have moved away from being almost "piloted" by the owners - since it was the club itself which elected the official representatives and chairmen of the fan clubs - to assuming an independent role not only towards the football club, but also towards other 
stakeholders such as institutions $^{46}$. Partner's strategic behaviour is therefore distinguished by a high level of freedom of opinion and action toward the football club, but also by their inclination to be "propositively open". At the same time, the football club acts towards the partners in a spirit of dialogue and negotiation, involving them in its strategic choices. For example it usually invites them to official meetings, local and national conferences, where other stakeholders take part, first and foremost local government, institutions responsible for public order, etc.

\section{Fans' inclination to cooperate}

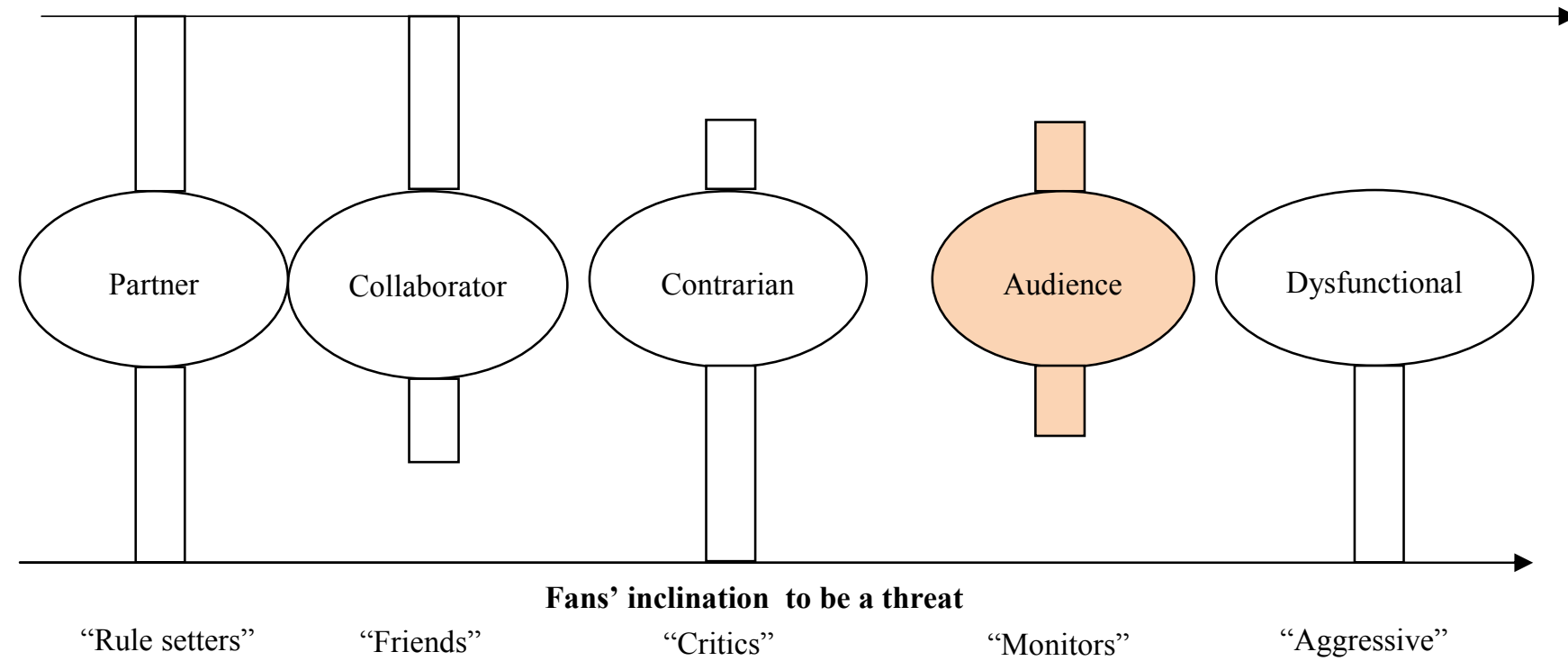

Figure 6. Strategic postures of fans as a stakeholder Source: Adapted from (Freeman 2007).

The group-defined collaborator is characterised by a high level of co-operation and a relatively low threat potential. As with partners, the activities performed by this segment of fans assume a "collective" dimension: it is not the single fan that acts, but rather the association coordinating the fan clubs. The strategic behaviour of the collaborators aims to find "friendship and dialogue with the football club, thinking of football merely as an exciting sports event" ${ }^{\prime 4}$. Their aim is to keep in contact with, as well as co-ordinate, each fan club's activities, to maintain direct relationships with football clubs and institutions, and restore the human side to the match-event, for example by seeking moments of encounter with the opponents' supporters through the organization of convivial meetings, twin fan clubs, exchanges of team flags and jerseys, etc. Collaborators are an active but moderate part of the fan community. They play an important role in the success of the event in terms of safety and security. The "friendly" attitude of the fans towards their opponents' supporters can help football clubs, local government and the institutions responsible for public order to manage public safety ${ }^{48}$, welcoming "away fans" and controlling the areas around the stadium ${ }^{49}$.

\footnotetext{
${ }^{46}$ In Italy, the control of the fan club by the football club was justified by the relevant economic support given to the former, which very often in return entailed the possibility for the owners to name the majority of fan clubs' representatives and chairmen. See Papa, Panico (1993).

${ }^{47}$ See Sancassani, M. (2009). La voce dei tifosi. June, Italian Federation of Football Club supporters.

${ }^{48}$ For example, during the Champions League match Fiorentina-Liverpool (29/09/2009), some fans from the Collettivo Autonomo Viola (CAV) launched a twin fan club initiative with the English supporters, called the "Reds" after the colour of the team's jerseys, welcoming them before the match outside the stadium, exchanging flags and jerseys and expressing their friendship through chants and banners such as "Reds, your name is a legend".
}

${ }^{49}$ See $\S .2 .5$. 


\section{REFERENCES}

Baglioni, S., Bof, F., Fusetti, C. (2008). Calcio e capitale sociale: il caso del Barcellona FC, mès que un club. In F. Bof, F. Montanari, G. Silvestri (Eds.), Il management del calcio. La partita pì̀ lunga. Milano: Franco Angeli.

Ballerini, M., Brazzini, M. (2000). Autobiografia di una Curva. Dalla Fiesole con tutto il cuore i tuoi ultras. Firenze: Edizioni ANMA \& San Marco Sport Events.

Bardazzi, L. (2009). Firenze è autodistruttiva. Il mio futuro è in dubbio. Corriere della Sera, 1 Marzo.

Benassai, D. (1998). Firenze: un amore viola. Firenze: Edizioni Scramasax.

Burt, R. S. (1982). Toward a Structural Theory of Social Action. New York: Academic Press.

Burt, R. S. (1983). Range. In R. S. Burt, M. J. Minor (Ed.), Applied Network Analysis. A Methodological Introduction. Beverly Hills: Sage.

Coppini, A. (2009). L'informazione e l'eccesso di comunicazione: ostacoli immateriali e fisici alla realizzazione dello stadio senza barriere. Il caso Firenze e ACF Fiorentina. Università di Firenze, Aprile.

Cova, B. (1997). Community and Consumption. Toward a definition of the linking value of products or services. European Journal of Marketing, 31(3), 297-316.

Da Empoli, G. (2002). Overdose. La società dell'informazione eccessiva. Roma: Marsilio.

Elias, N., Dunning, E. (1989). Quest for excitement. Sport and leisure in the civilization process. Oxford: Basil Blackwell.

Finn, G. P. T., Giulianotti, R. (2001). Scottish Fans, not English Hooligans! Scots, Scottishness, and Scottish Football'. In C. L. Harrington, D. D. Bielby (Eds.), Popular Culture. Production and Consumption (pp. 314327). Blackwell Publishing.

Freeman, E. R. (1984). Strategic Management: A Stakeholder Approach. Pitman, Boston: MA.

Freeman, R. E., Harrison, J. S., Wicks, A. C. (2007). Managing for stakeholders. Survival, Reputation, and Success. New Haven and London: Yale University Press.

Freeman, L. C., White, D. R., Romney, A. K. (Eds.) (1992). Research Methods in Social Network Analysis. Fairfax, VA: George Mason University Press.

Galaskiewicz, J., Wasserman, S. (1989). Mimetic processes within an interorganisational field: An empirical test. Administrative Science Quarterly, 34, 454-479.

Gummesson, E. (2006). Marketing relazionale. Milano: Hoepli.

Håkansson, H., Snehota, I. (1995). Analyzing business relationships. In D. Ford (Ed.), Understanding Business Markets (pp. 151-75). London: The Dryden Press.

Harada, M., Saito, R., Hirose, M. (2009). Segmentation of sports fans using the experiential value scale. Conference Proceedings, $17^{\text {th }}$ Annual European Sportmanagement Conference EASM, Amsterdam, 16-19 September, 2009.

Harrison, J. S., Bosse, D. A., Phillips, R. A. (2009). Managing for stakeholders, stakeholder utility functions and competitive advantage. Working Paper. VA: University of Richmnond.

Hunt, K. A., Bristol, T., Bashaw, R. E. (1999). A conceptual approach to classifying sport fans. Journal of Services Marketing, 13(6), 439-452.

Kozanli, A., Samiei, M. (2007). Segmenting the football audience. A market study based on live attendance. Master Thesis, Stockholm University School of Business.

Le Bon, G. (2007). La psicologia delle folle. Seconda Edizione.

Lega Calcio (2009). Analisi del trend degli spettatori allo stadio e degli ascolti televisivi della Serie A TIM e della Serie B TIM. Maggio.

Lusch, R. F., Vargo, S. L. (2006a). Service-dominant logic: reactions, reflections and refinements. Marketing Theory, 6(3), 281-288.

Lusch, R. F., Vargo, S. L. (Eds.) (2006b). The Service-Dominant Logic of Marketing: Dialog, Debate, and Directions. Armonk, NY: ME Sharpe.

Mitchell, R. K., Agle, B. R., Wood, D. J. (1997). Toward a theory of stakeholder identification and salience: defining the principles of who and what really counts. Academy of Management Review, 22(4), 853-886.

Normann, R., Ramirez, R. (1995). Le strategie interattive di impresa. Milano: Etas Libri.

Papa, P., Panico, G. (1993). Storia sociale del calcio in Italia. Bologna: Il Mulin.

Poesio, E. (2009). Poveri, ma belli. Corriere della Sera, Venerdì 3 Luglio.

Prandelli, N. (2008). La tessera del tifoso tra vincolo e opportunità: il caso della ACF Fiorentina. Università di Firenze, Novembre.

Rowley, T. (1997). Moving beyond Dyadic Ties: A Network Theory of Stakeholder Influences Author(s)'. The Academy of Management Review, 22(4), October. 
Salvini, A. (Ed.) (2007). Analisi delle reti sociali: teorie, metodi, applicazioni. Milano: Franco Angeli.

Sancassani, M. (2009). La voce dei tifosi. Italian Federation of Football Club supporters, June.

Scott, J. (2000). Social Network Analysis: A Handbook. London: Sage.

Sutton, W. A., McDonald, M. A., Milne, G. R. (1997). Creating and fostering fan identification in professional sports. Sport Marketing Quarterly, 6(1), 15-22.

Tapp, A., Clowes, J. (2002). From carefree casuals to professional wanderers: segmentation possibilities for football supporters. European Journal of Marketing, 36(11-12), 1248-1269.

Vargo, S. L., Maglio, P. P., Akaka, M. A. (2008). On value and value co-creation: A service systems and service logic perspective. European Management Journal, 26, 145-152.

Zagnoli, P., Fanti, D., Radicchi, E., La Manna, E. (2004). L'identità collettiva viola”. Analisi socio-economica degli abbonati della ACF Fiorentina (2003-2004). Università di Firenze, Giugno.

Zagnoli, P., Radicchi, E. (2008). Sport Marketing. Il nuovo ruolo della comunicazione. Milano: Franco Angeli.

Wasserman, S., Faust, K. (1994). Social Network Analysis: Methods and Applications. New York, NY: Cambridge.

AUTHOR'S ADDRESS: $\quad$ Patrizia Zagnoli

Laurea Specialistica in Management dello Sport

Università degli Studi di Firenze

Viale Morgagni 63, 50134 Firenze, Italy

Email: zagnoli@unifi.it 